\title{
Aleksandra Ubertowska
}

\section{„Kamienie niepokoją się i stają się agresywne”. Holokaust w świetle ekokrytyki}

\author{
Historia nie jest już po prostu historia ludzi, \\ lecz staje się również historią rzeczy \\ naturalnych.
}

\section{Bruno Latour ${ }^{1}$}

Kamienie niepokoją się i stają się agresywne. Zmienia się substancja rzeki.

\section{Piotr Rawicz}

Problematyka natury, krajobrazu, świata roślin i zwierząt w relacji wobec Zagłady Żydów w zasadzie nie znalazła się w horyzoncie dotychczasowych badań nad reprezentacjami Holokaustu, choć semantyka organicystyczna, ekologiczno-środowiskowa wydaje się istotną częścią wielu kanonicznych filmów czy tekstów literackich o Holokauście. Wystarczy przywołać obraz krwistoczerwonego jesiennego lasu wokół obozu zagłady w Shoah Claude’a Lanzmana czy wątek pierwotnej puszczy w filmie Opór Edwarda Zwicka ${ }^{3}$, motywy ukrywania się $w$ ziemiankach, bunkrach, dołach wykopanych w ziemi w prozie Henryka Grynberga czy Wilhelma Dichtera, rolę materii organicznej w obrazach Jonasza Sterna, Erny Rosenstein, Anzelma Kiefera, reportażach Racheli Auerbach, poezji Jerzego Ficowskiego, powieści Piotra Rawicza. Symboliczna obecność natury wręcz narzuca się jako nieusuwalny element wielu dzieł podejmujących problem Holokaustu.

3 Na temat wizualnych ram przedstawienia Zagłady w interesujący sposób pisze Bartosz Kwieciński [2012] w książce Obrazy i klisze. Między biegunami wizualnej pamięci Zagtady. 
Wydaje się, że jedynym powodem badawczego pominięcia, przeoczenia tych obrazów, tak sugestywnych i ważnych dla semantyki wspomnianych dzieł, była dominacja paradygmatu antropocentrycznego w naukach humanistycznych. Tendencja ta nie tylko nie pozwalała na postrzeganie natury jako czynnika sprawczego whistorii, ale widziała ją wręcz jako nieoznaczoną, pasywną, przezroczystą. A przecież environmentalism ${ }^{4} \mathrm{i}$ holocaust and genocide studies łączy bardzo wiele; wyznaczane przez nie badawcze trajektorie przecinają się (a raczej mogłyby się przecinać) w wielu punktach, w których przy pomocy innych słowników i metodologii artykułowane są analogiczne problemy historiograficzne i ontologiczne. Należy zatem zrekonstruować bieg tych trajektorii, podjąć próbę re-lektury i reinterpretacji literatury o Holokauście z perspektywy ekokrytyki i krytyki środowiskowej, a zatem sprawdzić nowe możliwości badawcze, które (to istotna informacja) nie stworzyły jeszcze ustabilizowanej metodologii.

Najbardziej wyrazista analogia zawiera się w samych podstawach obydwu dyscyplin. Przedstawicieli krytyki środowiskowej i historyków Zagłady łączy myślenie w kategoriach totalnej katastrofy: geno- i ekocydu. Saul Friedlander [1992: 5; przeł. - A.U.] nazywa Holokaust „trzęsieniem ziemi, które zniszczyło wszystkie instrumenty pomiarowe”, podkreślając przy pomocy tej geotektonicznej metafory nieporównywalny wymiar nazistowskiego ludobójstwa. W tej samej poetyce określają znaczenie Holokaustu dla zbiorowej świadomości inni filozofowie, którzy mierzą się z tym zagadnieniem. Dla Emmanuela Levinasa [2000: 133] Zagłada zaznacza moment „bezkrólewia, zawieszenia samego bycia”, dla Hannah Arendt jest równoznaczna z zerwaniem, rozpostarciem „przepaści, otchłani” (Abgrund) [Rabinbach 2003: 64; przeł. - A.U.] barbarzyństwa, która zmusza do przemyślenia podstaw kultury europejskiej. Dla filozofów postrukturalistycznych

Istnieje już w polskiej nauce dość ciekawa literatura przedmiotu z zakresu szeroko pojętej humanistyki nieantropocentrycznej, głównie skoncentrowanej na obszarze animal studies, lecz również wykorzystującej inspiracje plynące ze strony krytyki środowiskowej i ekokrytyki [zob. Czapliński 2012; także monograficzny numer „Tekstów Drugich” 2013, nr 1-2, w którym opublikowano m.in. artykuły Ewy Domańskiej i Aleksandry Ubertowskiej - zob. Bibliografia]. 
Holokaust zapoczątkowuje nowy czas, od którego cała przeszłość będzie musiała być ujmowana $\mathrm{w}$ „nekrospektywie” (termin Jeana Baudillarda [1992: 104]), a więc w perspektywie śmierci wartościs.

Podobną stylistyką operuje Franz J. Broswimmer [2002], krytyk środowiskowy i twórca pojęcia „ekocydu”, który w jego ujęciu jest tożsamy z masowym wytępieniem gatunków, wywołanym przez rewolucję neolityczną: upowszechnienie ekstensywnej uprawy ziemi i skolonizowanie przez człowieka wielkich ekosystemów. Inni environmentaliści, jak Mark Levene [2013: 152; przeł. - A.U.], dążą do redefinicji „historii” i „historyczności”, zakładając, że „historia nie jest atrybutem jedynie człowieka, lecz ziemi samej, życia na ziemi”. Efektem wprowadzenia tych nowych praktyk myślowych staje się „rekonfiguracja aspektów ludzkich”, wpisanie ich w szerszą perspektywę geologiczną i planetarną, ukazującą wzajemne oddziaływanie na siebie natury i historii. Badacze środowiskowi koncentrują się zwłaszcza na krytycznym opisie antropocenu - ery geologicznej, której początek datowany jest na koniec wieku XVIII ${ }^{6}$. Wówczas rozpoczął się okres nieokiełznanej przemocy człowieka nad naturą. Przejawem tej przemocy stał się gwałtowny wzrost emisji dwutlenku węgla i deforestyzacja - wyrąb lasów na skalę przemysłową. Antropocentryczna sprawczość zmieniła fundamenty biosferycznego przepływu energii - po raz pierwszy wpływ człowieka na naturę przewyższył oddziaływanie natury na człowieka. Dlatego Levene [2013: 153; przeł. - A.U.], parafrazując wypowiedź Dipesha Chakrabarty'ego, nazywa tę fazę okresem „upadku człowieka w antropocen”, podkreślając, że ostatnie dwa wieki są czasową rupturą, , czasem kairotycznym” w historii zapowiadającym całkowitą zagładę człowieka i świata.

Zarysowuje się tu uderzająca analogia do ujęć czasowości, jakie napotykamy w badaniach nad kulturowymi źródłami Holokaustu. Nietrudno zauważyć, że ramy czasowe „antropocenu”

5 Pisałam na ten temat w swojej książce Świadectwo, trauma, gtos. Literackie reprezentacje Holokaustu [Ubertowska 2007].

6 Nazwa została wprowadzona przez ekologa Eugene'a Stoermera i laureata Nagrody Nobla chemika Paula Krutzena. Ma ona charakter nieformalny, ale przyjęła się w studiach środowiskowych i ekokrytyce [por. Chakrabarty 2014: 181-186]. 
niemal pokrywają się z okresem nowoczesności, który w refleksji Theodora W. Adorna i Maxa Horkheimera, w eseistyce Zygmunta Baumana, Jeana-François Lyotarda i Maurice'a Blanchota jawi się jako formacja historyczna pełna sprzeczności, niepojętych aporii, krótkotrwałych regresów, poznawczych i etycznych zapętleń. Z jednej strony jest to formacja emancypacyjna, akcentująca prawo do wolności i wiarę w nieograniczone możliwości poznawcze człowieka; z drugiej - niepostrzeżenie przeradzająca się w post-oświeceniową tyranię nad kulturową innością, tym, co „ciemne”, „niedojrzałe”, lokalne, pragmatyczne, jest także epoką, popadającą w mityczną zależność od rozumu, scjentyzmu i świadomości.

Swoisty wzorzec myślenia w takich kategoriach stworzyli Adorno i Horkheimer [1994] w swojej książce Dialektyka Oświecenia. W rozprawie tej wskazano na równoległość czasową trzech procesów: narodzin nowoczesności, ostatecznego zawładnięcia naturą i powstania współczesnego antysemityzmu, który doprowadził do ludobójstwa europejskich Żydów. Wedle Adorna i Horkheimera [1994: 22] podstawą ideologii europejskiego modernizmu był skrajny antropomorfizm przyjmujący formę „projekcji podmiotowości w przyrodę”. Dzięki temu zabiegowi człowiek nie tylko uwolnił się od strachu przed siłami natury, lecz także zdobył nad nimi władzę totalitarną („Oświecenie jest totalitarne” [Adorno, Horkheimer 1994: 22]). Oświeceniowy podmiot „stał się jedynym, nieograniczonym, pustym autorytetem. Wszelka siła natury jest już tylko niezróżnicowaną magmą, stawiającą opór abstrakcyjnej władzy podmiotu" [Adorno, Horkheimer 1994: 107]. Antysemityzm jest ściśle powiązany z tą oświeceniową krucjatą przeciwko naturze. Żydzi bowiem wedle Frankfurtczyków padają ofiarą zbiorowej nienawiści, ponieważ nie zerwali całkowicie z naturą; pamięć o mimetyzmie czlowieka wobec natury przechowali w pieczołowicie przywolywanych rytuałach, a zatem $\mathrm{w}$ formie konsyliacyjnej, w której zawiera się zarazem moment przezwyciężenia natury, jak i świadomość jej głębokiej ciągłości i więzi z nią.

A zatem od kantowskich źródeł modernizmu krótka droga prowadzi do rasistowskich praktyk kierowanych przeciwko Żydom, Romom, Słowianom, osobom psychicznie chorym. Formacja ta 
jest bowiem zarazem antropo- i europocentryczna; jak twierdzi Timothy Morton [2012: 8; przeł. - A.U.], dopiero ekokrytyka i teoria postkolonialna zerwały z przeświadczeniem, że „tylko ludzie, lub inaczej - świadomość może nadawać rzeczywistości wartość i znaczenie, że tylko biali mężczyźni - Europejczycy są podmiotami sprawczymi historii”.

Podobne zagadnienia wytyczają horyzont myślenia w rozprawie Zygmunta Baumana [1992] Nowoczesność i Zagłada. Zdaniem jej autora Holokaust - „rzecz przeprowadzona w sposób nowoczesny - racjonalny, planowy, oparty na naukowej informacji, ekspertyzie, fachowym zarządzaniu i kierowaniu” [Bauman 1992: 133] - był wytworem praktyk ekonomicznych, społecznych, państwowych typowych dla kultury nowoczesnej, które nadal determinują kształt cywilizacji euroatlantyckiej. Co ciekawe, Bauman dostrzega związek między rozwojem technologicznym, tak charakterystycznym dla nowoczesności, a deklarowanym przez modernistów odejściem od harmonijnego związku z naturą i narzuceniem jej ludzkiej dominacji. Wszystkie te zjawiska skłoniły go do określenia nowoczesności mianem „kultury ogrodniczej”:

Nowoczesna kultura jest kulturą ogrodniczą. Definiuje samą siebie jako wzór idealnego życia i doskonałej organizacji warunków ludzkiego istnienia. Konstruuje swoją tożsamość z braku zaufania do natury. W rzeczywistości definiuje siebie, naturę i różnice, które je dzielą w oparciu o lepszy, koniecznie sztuczny porządek. [Bauman 1994: 138]

Przykładem kontradykcji określającej modernizm wydaje się również koncepcja nowoczesności Brunona Latoura [2011], która w znacznej mierze łączy zarysowane tu perspektywy: środowiskową i historyczną. W ujęciu Latoura dynamikę ruchu nowoczesnego determinują dwa wektory: translacji (a zatem akceptacja różnorodności, hybrydyczności) i puryfikacji (czyli podtrzymywania i utrwalania granic pomiędzy przestrzeniami natury, społeczeństwa, dyskursu). A przecież kantowski wzorzec człowieka świadomego dostarczył legitymizacji dla nazistowskich praktyk usuwania „brudu społecznego”: homoseksualistów, Żydów, osób 
chorych psychicznie. Praktyki te niewątpliwie były przedłużeniem działania Agambenowskiej „machiny antropologicznej”. Latour proponuje zatem odrzucenie „antropomorfizujących” tendencji (quasi-)modernistycznych na rzecz „morfizmów”. W myśl tej nowej filozofii społecznej człowiek nie byłby „koroną stworzenia”, bytem uprzywilejowanym, lecz „tkaczem morfizmów” [Latour 2011: 194], twórcą sieci złożonych z organizmów ludzkich, zwierzęcych, bytów roślinnych, rzeczy etc.

Podobne utopijne wizje, zarysowujące koncepcje społeczeństw przyszłości napotykamy w wielu wypowiedziach krytyków środowiskowych. Mick Smith [2013: 27] głosi potrzebę odrzucenia paradygmatu cywilizacyjnego, wedle którego natura traktowana jest jako źródło zasobów poddawanych utylizacji i użytkowanych przez człowieka. Postuluje również utworzenie ekologicznych wspólnot ponadgatunkowych, które byłyby realizacją ideału being singular plural Jeana-Luca Nancy [Smith 2013: 29] (wielogatunkowego „my”), określającego „kondycję światową” przyszłego człowieka. Określenie „uprzedmiotawiający nihilizm”, zaproponowane przez Mortona [2012; przeł. - A.U.] wydaje się precyzyjnie nazywać zarówno destrukcyjną postawę człowieka wobec świata natury, jak i organizację ludobójstwa „na przemysłową skalę”, zakładającą traktowanie Innego jak „czystego zasobu”.

Semantyka natury w interesujący sposób ujawnia się w jednej z ostatnich książek Dominicka La Capry, uznanego teoretyka kultury posttraumatycznej mierzącej się z dziedzictwem Holokaustu. W książce History and It's Limit La Capra [2010] zajmuje się zagadnieniami z zakresu animal studies i ponownie - tym razem częściowo w perspektywie ekokrytycznej - problematyką świadka, świadectwa, sztuki o Zagładzie. W eseju Traumatropizmy [La Capra 2009], poświęconym figurze wtórnego świadka, fundamentem wywodu myślowego La Capry jest metafora roślinna, której pierwotne znaczenie objaśnia hasło encyklopedyczne dołączone do tekstu w formie motta. Traumatropizmy to "chorobliwe” narośla lub krzywizny w budowie organizmów roślinnych wyrastające z miejsca zranienia; to zrosty zalepiające ranę, a zarazem ustanawiające ślad choroby; to coś kalekiego, a zarazem nieusuwalnego, istniejącego w sposób niepodważalny. Wątek trauma- 
tropizmów pojawia się tylko w „paratekstualnej” warstwie eseju; nie został on rozwinięty czy objaśniony w samym tekście, a jednak stanowi niezbędny element wywodu autora - nie można go zastąpić żadną inną figurą retoryczną.

W centrum swojego eseju La Capra umieszcza postać wtórnego świadka/świadectwa, którego istotę określa nie tyle udział w wydarzeniu historycznym, jakim był Holokaust, czy też identyfikacja z nim, ile „empatyczne nieuposadowienie” (empathic unsettlement), rozumiane przez La Caprę jako afektywna odpowiedź na wydarzenie graniczne połączone z krytycznym dystansem, intelektualną zdolnością do wydania sądu. W istocie bowiem każda reprezentacja Holokaustu jest „sekundarna” - oddalona od swojego źródła i - co się z tym wiąże - nieuchronnie naznaczona skłonnością do wzniosłości, dwuznacznej estetyzacji śladów po nazistowskim ludobójstwie (jak sterta butów w muzeum w Majdanku), a nawet do sakralizacji tego doświadczenia. Dlatego można powiedzieć, że każde świadectwo Holokaustu jest traumatropizmem, transfiguracją rany - chorobliwą naroślą niweczącą tradycyjne dychotomie fikcji i dokumentu, sztuki i życia, realizmu i wzniosłości, a zarazem „zarastającą” te pęknięcia w procesie zdrowienia.

W tym miejscu pojawia się pytanie: jakie wartości wnosi do dyskursu nad reprezentacjami Holokaustu tytułowa metafora roślinna? Dlaczego wydaje się tak niezbędna w konstrukcji wywodu? Na pewno wychodzi ona naprzeciw przeświadczeniu o nieopisywalności Holokaustu, o bezradności istniejących estetyk i konwencji przedstawienia. Opis świadectwa Zagłady wyłania się tu z niemożliwego odstępu pomiędzy skompromitowanymi poetykami - z tajemniczego, pierwotnego świata roślin. Ten kontekst defamiliaryzuje (dość zbanalizowany) obraz rany, złamania, choroby, przenosząc go na poziom fundamentalnej refleksji o życiu, przekraczającej granice międzygatunkowe czy rodzajowe.

\section{Krew nieba: w poszukiwaniu narracji organicznych}

Krew nieba Piotra Rawicza [2003] - powieść o niezwykle złożonej konstrukcji rozwijającej się między biegunem autobiograficznego świadectwa a fantasmagoryczną wizją świata popadającego 
w chaos - w sposób wprawdzie nieoczywisty, ale zdecydowany wpisuje się w zarysowaną tu poetykę ekokrytyczną. Odniesienia organiczne/ekologiczne, choć często balansują na granicy stosowności, zbliżając się do przedstawień sublimicystycznych i epatujących hiperbolicznym okrucieństwem, są niezwykle przekonujące - zarówno jako gesty artystyczne, jak i przyczynek do wykładni historiozoficznej, sytuującej Holokaust w perspektywie historii naturalnej. Osiągnięcie tego efektu stało się możliwe dzięki osadzeniu fikcyjnej, czasami nawet surrealistycznej wizji [Gośclicki 2003; Rosenfeld 2003] w konkretnej, rozpoznawalnej przestrzeni lwowskiego getta, Lasów Janowskich, Zakopanego, galicyjskich pejzaży kulturowych - a zatem dzięki praktykom przypominającym freudowską kategorię das Unheimliche - szoku i horroru, który dzieje się w przestrzeni swojskiej, domowej.

Już tytuł tej powieści zarysowuje fundamentalną dla jej wymowy paralelę pomiędzy światem ludzkim, historycznością a pejzażem, fakturą i odrębnym porządkiem bytów organicznych, które wpisują się w dynamikę rytmów kosmicznych. Zagłada jest tu figuralizowana jako brutalna ingerencja w porządek natury, jako nacięcie, rana na firmamencie nieba. Sam tytuł powieści Rawicza mógłby wprawdzie zostać zinterpretowany jako naiwna antropomorfizacja czy obraz ciążący w stronę kiczu, jednak uszczegółowienie przyświecającej mu idei, jakie następuje w kolejnych fragmentach tekstu, przynosi pogłębienie zasygnalizowanej tu problematyki. Okazuje się, że semantyka tytułowego metaforycznego obrazu „krwi nieba” ma na celu raczej silne zespolenie Zagłady wspólnoty żydowskiej i życia natury; jest zatem wykonanym jednocześnie gestem częściowej antropomorfizacji natury i „naturalizacji” ludzkiego doświadczenia. Spotykają się one „w pół drogi”, wzbogacając się wzajemnie, wydobywając z „ludzkiego” i „zwierzęcego" ukryte, dyskretne znaczenia, które pozostają wobec siebie w relacji Latourowskiej „cyrkulującej referencji” [Latour 2000].

W Krwi nieba samo zamieszkiwanie w getcie zakorzenia bohaterów w świecie natury.

Widząc mnie wchodzącego pewnego wieczoru, Leon L. dźwignął się ciężko z fotela: W moim życiu, które wkrótce 
dobiegnie kresu - rzekł - pragnę już tylko jednej rzeczy - znaleźć się ponownie w mojej wiejskiej posiadłości i powłóczyć się brzegiem wielkiego stawu. Poczuć zapach wodnej roślinności.

To nie ów nagły przypływ miłości do natury mnie uderzyl, lecz sposób jej wyrażania, taki lakoniczny i bezpośredni. Mury szczelnie zakrywały przed nami rozległy krajobraz, lecz za to - i na przekór zamknięciu nas w miejskości stawaliśmy się sami integralną cząstką przyrody na sposób bardziej niż kiedykolwiek dotykalny. Śmiertelny głód i śmierć nawiedzały nasze oczy. Pośrodku ulicy potykaliśmy się o trupy przykryte starymi gazetami. Elementarne organiczne procesy gnicia, spalania się, przekształcania życiodajnych soków w martwą ciecz zawładnęła naszymi zmysłami. Braterskie obcowanie ze szczurami, wszami, pluskwami otwierało nasze oczy na wszechogarniającą naturę mrowiącego się kłębowiska - owo wspólne i mało chwalebne przeznaczenie materii żywej. Ta fizyczna bliskość ognia i rozkładu, już pożerających nasz naród sprawiała, że bardziej bezpośrednio braliśmy udział w tchnieniu wszechświata. [Rawicz 2003: 39]

Los żydowskich ofiar, stłoczonych w getcie, skazanych na masowe wyniszczenie, objawia się tu jako stopniowe przekształcanie się w materię nieorganiczną, jako roztapianie się w „pramaterii”, w której zanikają podziały na poszczególne byty. Człowiek traci tu swoją uprzywilejowaną pozycję, porzuca status monady, bytu osobnego, posiadającego świadomość, i włącza się w ciąg procesów organicznych: rozpadu, gnicia, spopielenia. Postać ludzka - narrator, bohater - sytuuje się w perspektywie mikrokosmicznej - ogląda i opisuje świat z punktu widzenia insektów, mikrobów, istnień najniższych, traktując ten stan jako ważne doświadczenie poznawcze, zakładające przekroczenie antropocentrycznych podziałów.

Podobnym przemianom podlega w powieści Rawicza ujęcie czasu, który przestaje być wartością abstrakcyjną, umowną, odseparowaną od cielesności i materialności, „nadbudowaną” nad wydarzeniami historycznymi. Jak powiada narrator, „czas teraź- 
niejszy, czas obecny - on jest tutaj, niczym masa mięsa wysuszonego przez niedobre słońce" [Rawicz 2003: 25].

Czas staje się czasem organicznym, dotykalnym, podlegającym rozpadowi. Nabiera cech materii ożywionej (choć poddawanej systematycznemu wyniszczeniu), wydaje się porowaty, chropawy, ale i zmieniający swój stan skupienia. Narrator nazywa cechę dominującą nowej czasowości - jest nią „mięsność”, a zatem również podatność na zjadanie, gnicie, rozkład, co sugeruje figurę samopożerającego się czasu - czasu powszechnej destrukcji. Jest on również opisywany jako część lub aspekt coraz bardziej jednorodnej, organicznej całości, wnika on w człowieka i razem z nim ulega procesom rozkładowym.

W ten sposób w powieści Rawicza dokonuje się podważenie modernistycznego paradygmatu, w myśl którego natura jest postrzegana jako chaotyczne, nieforemne tworzywo, zawsze pozycjonowane jako przedmiot podporządkowany dominacji ludzkiego podmiotu. W tej opowieści o Zagładzie „roztopienie” tego, co ludzkie, w świecie natury jawi się jako fakt neutralny, a może nawet pozytywny - jako schronienie w naturze, w jej dobroczynnym, ocalającym świecie.

Omszały kamień służący mi za poduszkę był niczym innym, jak pretekstem. Nieruchomość mego ciała ukrytego za skałą stanowiła szeroką i królewską drogę ku przeżyciu. Zamilkł ostry terkot karabinów maszynowych i upływające godziny pieścily niebo niczym czarne ptaki. Z głębiny mojej studni rozpłaszczony jak pluskwa o dwóch jedynie wymiarach, patrzą, jak niebo spokojnie oddycha: Ukatrupić to niebo, zobaczyć krew nieba... Obrazy się jawią rozproszone i słowa nigdy niewypowiedziane. Ruchem tak niepostrzeżonym, że zdaje się rodzić gdzie indziej, kieruję wzrok ku równinie. Widzę ją z bardzo daleka, jak przez odwrotną stronę lornetki. Para dziecięcych bucików, lalka co została, nieskalany, jedwabny stanik ... To tam bije źródło. Pomiędzy historią z drzwiami przed chwilą zatrzaśniętymi a muzeum jeszcze nie otwartym [...]. [Rawicz 2003: 30] 
Motywy natury występują w Krwi nieba Rawicza również w nieco innym kontekście, dotyczącym problematyki reprezentacji historii i Zagłady Żydów. „Omszały kamień” okazuje się „pretekstem”, ale i „pre-tekstem” - tekstem pierwotnym, reprezentacją najbardziej elementarną, obywającą się bez zapośredniczeń. Porowaty, omszały kamień funkcjonuje tu jako „źródło” opowieści o Zagładzie, jako jej wzorzec bezskutecznie naśladowany przez narratora. Od „omszałego kamienia" rozpoczyna się szaleńcza opowieść o ucieczce z getta narratora Piotra i jego towarzyszki Anki przez okupowaną przez Niemców Galicję, opowieść tak niewyobrażalna, że rozsadza ramy istniejących konwencji narracyjnych. „Kamień” staje się tu symptomem pragnienia „prawdziwej”, stabilnej opowieści, fantazmatem stałości, fundamentu, którego nie będzie można już zakwestionować.

W przytoczonym wyżej cytacie został uchwycony moment rozprzężenia, rozpadu „antropomorficznego” obrazu ludobójstwa. W prześwicie pomiędzy ludzkimi językami opisu: faktograficznością historii (obraz masowych egzekucji w Lasach Janowskich) i instytucjami upamiętniającymi ową historię (muzeum) dochodzi do głosu język natury. Biernie, bezrefleksyjnie rejestruje on przepływ obrazów, które nie są uporządkowane, uhierarchizowane czy ujmowane z perspektywy stabilnego autorytetu narracyjnego: są wśród owych bezładnych obrazów przedmioty pozostawione przez umarłych, daleki zarys egzekucji, bezkresny widnokrąg nieba. Obrazy te są jakby pozbawione ramy znaczeniowej, wolne od historyczności, przedkognitywne, a zarazem przejmujące, dotkliwe (niemal dotykające powierzchni naszej skóry).

Właśnie w tym „prześwicie” pomiędzy historią i jej instytucjami uzgadniane i negocjowane są warunki opowiadania o ludobójstwie, „ustawiony” zostaje głos narratora, jego relacja wobec różnych obszarów rzeczywistości. Natura, krajobraz, materie organiczne (piasek, mech, ziemia, pleśń) mają zatem w ontologii Rawicza również wymiar meta-diegetyczny, zajmując swoje miejsce w estetycznej debacie nad niewyrażalnością Holokaustu i w próbach stworzenia przeciw-dyskursu, odrzucającego tradycyjne, antropocentryczne formy reprezentacji . 
Opowiadający wstaje, wprawiony w ruch jakimś nieokreślonym uczuciem, właśnie dokonuje się zmiana dekoracji. Mamy w tym jakiś udział? Kamienie niepokoją się i stają się agresywne. Zmienia się substancja rzeki. Poniżej naszych stóp to już nie jest woda, tylko jakaś czarna ciecz, smoła, w której odbijają się żółte światełka, co przywędrowały znikąd. Noc jest aż za gęsta, aczkolwiek jakby stoczona przez robaki. Uroczyste procesje spóźnionych szczurów wpatrują się w miejsce, gdzie powinien był ukazać się księżyc. Wypowiada chmurom pojedynek, z góry wiedząc, że jest on przegrany. [Rawicz 2003: 135]

Istnieje zatem związek pomiędzy „performatywną” siłą opowiadania a procesami zmian w świecie natury - obydwa te porządki oddziałują na siebie. „Agresywność” kamieni, ciemnienie wód to reakcje na opowieść o ludobójstwie, które przekształca elementy natury, określa na nowo ich status, przede wszystkim wytrącając je z pierwotnego porządku. Natura wchłania atrybuty holokaustowej narracji, jej oszalały, niepokojący rytm, nieustanną nieprzezroczystość, matowość przedstawienia, czyli niemożność opowieści o Zagładzie. Krajobraz staje się zaś coraz bardziej wystylizowany, nabiera cech alegorii lub teatralnej scenografii, „świadkującej” traumatycznym przeżyciom bohatera. Wytwarza się tu zatem coś na kształt Latourowskiej naturo-kultury [Latour 2011], całości, zawieszającej podziały, wytwarzającej ponadgatunkowe powiązania i zespolenia. W jakimś sensie tylko dzięki „eskapistycznej” perspektywie, jaką stwarza natura, i dzięki utopijnej wizji „nowej całości” okrutna galicyjsko-żydowska opowieść Rawicza jest możliwa do zniesienia w lekturze.

\section{Ocalająca moc ziemi. Motywy chtoniczne}

Kontynuując myśl z początkowych fragmentów artykułu, która dotyczyła przełamywania paradygmatu modernistycznego zarówno w myśleniu ekologicznym, jak i w refleksji nad cywilizacyjnymi przyczynami ludobójstwa europejskich Żydów, chciałabym przywołać interesującą wypowiedź Claude’a Levi-Straussa, który stwierdził, że u źródeł każdego mitu leży nieredukowalna różnica 
pomiędzy istnieniem „chtonicznym” $\mathrm{i}$ „autochtonicznym” [Morton 2012: 16; przel. - A.U.], a zatem formą życia wywodzącą się z ziemi i formą istnienia „z własnego nadania”, ufundowanego przez suwerenną jednostkę ludzką. W antropologii Levi-Straussa to mit legitymizował człowieka autochtonicznego, tworzącego kulturę autonomiczną, oderwaną od świata natury. Historia ludzkości rozpoczęła się dopiero od tego założycielskiego gestu „zabicia” w sobie pamięci o pochodzeniu naturalnym, o organiczności naszego ciała.

Literatura o Zagładzie i tu wprowadza komplikacje i rewizje, niejako odwracając logikę linii rozwojowej, w której „chtoniczność" byłaby jakością anachroniczną, zakorzeniającą ludzkość w zwierzęcości, zaś „,autochtoniczność” mieściłaby się w narracji postępu, rozwoju cywilizacyjnego ludzkości głoszącej, że natura jest kłopotliwym dziedzictwem, które należy w sobie przezwyciężyć. W eseistyce Prima Leviego, prozie Wilhelma Dichtera i Henryka Grynberga to właśnie „autochtoniczność” jawi się jako synonim złowieszczej pychy człowieka, jego niepohamowanej żądzy panowania nad światem, „chtoniczność” zaś sytuowana jest w kontekście znaczeń opiekuńczych, ciepłych, matczynych, jako synonim schronienia czy azylu przed szaleństwem i okrucieństwem historii. Uciekinierzy z gett czują się porzuceni przez całą ludzkość, skrajnie osamotnieni; okazuje się, że jedynie natura pełni tu funkcję prowizorycznego „domu”, przestrzeni swojskiej, bezpiecznej, do której historia nie ma dostępu.

Kryliśmy się w lesie do zmierzchu. Siedzieliśmy pod rozłożystymi, iglastymi drzewami, przy pniu, gdzie było zacisznie i sucho. Nisko wyrastające gałęzie spływały do samej ziemi, tworząc gęsty, cienisty parasol. Tylko osypujące się, suche igły wplatały się we włosy i kłuły wpadając za kołnierz. [Grynberg 1989: 20]

Ziemianka była wykopana głęboko, solidnie umocniona i wsparta nie struganymi palikami, wymoszczona gałęziami i słomą. Nie było w niej ani zimno, ani mokro i było dosyć miejsca dla wszystkich. Było tylko bardzo ciemno. W dzień jedyne światło dawały cieniutkie szparki zrobione specjalnie 
do oddychania, a w nocy nasze dyskretne ognisko lub księżyc. Zupełnie jakby na świecie była tylko noc. [Grynberg 1989: 28]

Przeświadczenie o niewinności natury, o jej niemo wyrażanym sprzeciwie wobec masowej zbrodni jest wielkim „mitem” literatury Holokaustu, ożywianym przez topos ukrywania się w podziemnych bunkrach, w skrytce za cembrowiną studni, w norach, jaskiniach lub leśnych szałasach ${ }^{8}$. Niejako zniesione tu zostaje przeciwstawienie natura devorans - natura devorata, które jest tak istotnym wątkiem dla polskiej świadomości historycznej i poezji (np. Miłoszowski Traktat moralny [Fiut 1998]). To właśnie ten wątek opowiada o unicestwieniu, zagładzie Innego jako prawie rzekomo determinującym świat przyrody; w zasadzie wątek natury pożeranej i pożerającej (jako zbyt nihilistyczny?) nie pojawia się w kontekście natury jako tła Holokaustu lub też pojawia się w postaci otamowanej, złagodzonej.

Znamiennym rysem problematyki ekologicznej we wspomnieniach holokaustowych wydaje się postrzeganie natury jako bytu autonomicznego, niepodatnego na praktyki translacyjne zawłaszczające jej swoiste cechy. Natura u Grynberga i Dichtera pozostaje wprawdzie „w relacji wobec” człowieka, czasami relacji niezwykle istotnej, jednak nie staje się obiektem agresywnych projekcji antropomorficznych, które byłyby formą użytkowania zasobów przyrody dla ludzkich celów. Zachowuje ona swoją suwerenność; jej domeną staje się „dyskretna obecność”, która jest odbierana przez zaszczutych uciekinierów z getta jako miłosierna i ocalająca. Istotny wydaje się fakt, że usytuowanie „w relacji do” pozbawione jest elementów hierarchizujących, struktur władzy i dominacji. Dlatego też w Żydowskiej wojnie czy powieści Dichtera natura jest w sensie ontologicznym prymarna, pierwotna: nie panuje, nie dominuje nad innymi bytami, lecz pozostaje fundamentem, podstawą świata i sądów formułowanych przez człowieka [Mazel 2000: 19].

8 Studium opisującym zjawisko kryjówek (również leśnych) z perspektywy socjologicznej i kulturowej (w zakresie badań nad przestrzenią) jest rozprawa Marty Cobel-Tokarskiej [2012], Bezludna wyspa, nora, grób. Wojenne kryjówki Żydów w okupowanej Polsce. 
Przy całej różnicy kontekstów i doświadczeń można dopatrzeć się tu analogii do haseł głoszonych przez ekoarchitektów patronujących budowie „podziemnych domostw” (jak Underhill Arthura Quarmby'ego w Anglii), które wydają się antidotum na kult wysokich, dominujących budowli wielkomiejskich - wskazują konieczność pozostania w łączności z ziemią, respektowaniem jej prawideł [Wines 2008: 92-93].

Moszek puścił moje ręce, a Kopcio wciągnął mnie przez dziurę w cembrowinie. Wpadłem na Niusię, która miała mokrą twarz. Potem zeszła matka. Niusia rzuciła się do niej. Obejmowały się i plakały.

Byliśmy pod ziemią.

W dzień było gorąco. Zlani potem, siedzieliśmy lub leżeli na glinie, która podchodziła wodą. Wszystko przenikał silny zapach ziemi i korzeni. Nusia siedziała oparta o ścianę w staniku, białej halce i majtkach. Byłem ciekaw, jak wygląda, ale nie mogłem zobaczyć jej twarzy. Przez szczeliny między kamieniami wpadało tylko kilka wąskich promieni światła, w których wirował kurz. Poza nimi było czarno. Widziałem więc jedynie to, na co padal promien. [Dichter 2000: 54-55]

Istnienie żydowskich zbiegów „zanurzonych” w ziemi ulega zmianie: wytraca swoją dynamikę, staje się statyczne, pozbawione ruchu i progresywności (pokonywania, zawłaszczania, podboju). Bohaterowie tkwią w bezruchu, otoczeni przez wrażenia zmysłowe, jakimi emanuje wnętrze ziemi. Doświadczenie to zawiera w sobie pewne elementy regresywne (odnosi się wrażenie, że jest to powrót do „łona” natury, do prapoczątków życia), przeważa jednak odczucie uczestniczenia w nowym (jakkolwiek dojmującym, pełnym cierpienia) wymiarze egzystencji. W tym kontekście podziemne bunkry, nory, wrośnięte w ziemię cembrowiny stają się odwrotnością, „pozytywem” grobu, masowego grobu - a zatem najbardziej negatywnych toposów literatury o Zagładzie.

Spojrzenie „z wnętrza ziemi” tworzy nową perspektywę opisu Zagłady, niejako spoza pozycji „sprawca - ofiara - świadek”, jakie wyznacza w swoim „trójkącie badawczym” Raul Hilberg [2007]. 
Nadal jest to punkt widzenia ofiary, przełamany jednak przez dodatkowy pryzmat, jakby bardziej obiektywizujący, „światowy”, nadbudowany nad wieloma jednostkowymi punktami widzenia. Nie jest to już ogląd cząstkowy, fragmentaryczny, lecz rozproszony, spoza horyzontu żydowskich bohaterów prozy Dichtera (choć nadal zawierający najistotniejsze przesłanie, wynikające $\mathrm{z}$ ich doświadczeń wojennych). Przywodzi na myśl ideę „spojrzenia bez podmiotu", które Georges Didi-Huberman [2008: 164] odnajduje w konstrukcji filmu Alaina Resnais Noc i mgła. To spojrzenie wedle francuskiego badacza jest pozbawione roszczeń do podboju lub uprzedmiotowienia innych bytów; zajmuje się raczej przetwarzaniem wielu mikrosygnałów, wypływających ze świata natury (zapachów, faktur, natężenia światła, oddechów i samopoczucia ludzi, zmienności pór roku etc.) i harmonizowaniem ich przebiegu. Spojrzenie to znosi dylematy, jakie ujawnia uruchomienie perspektywy historycznej, prawnej, teologicznej; przypomina raczej traumatropizm La Capry, formę „zarastającą” pęknięcia poznawcze i etyczne, jakie rodzi namysł nad Zagładą.

Konkluzją wypływającą z przedstawionych tu analiz, będących z konieczności jedynie zarysem najistotniejszych problemów rodzących się na styku studiów nad Zagładą i ekokrytyki, powinno stać się stwierdzenie, że inspiracje ekokrytyczne wnoszą bardzo wiele do już istniejącego obrazu literatury Holokaustu, „obrazu”, który tworzy literaturoznawstwo. Ważna, aktywna rola natury była bowiem zawsze niezbywalnym elementem dzieł artystycznych z tego obszaru; niezbywalnym, choć w przedziwny sposób ignorowanym. Dzięki ekokrytyce możliwe jest, jak się wydaje, usunięcie owych „ślepych plamek” badawczych, odarcie literatury Holokaustu $\mathrm{z}$ antropomorficznych uprzedzeń fałszujących w znacznym stopniu wiedzę z tego zakresu.

\section{Bibliografia}

Adorno Theodor W., Horkheimer Max (1994), Dialektyka Oświecenia, przeł. Magdalena Łukasiewicz, posłowie Marek Siemek, Wydawnictwo IFis PAN, Warszawa.

Baudillard Jean (1992), Tranzparenz des Bön. Ein Essay über extreme Phänomene, przeł. Martin Otz, Merve Verlag, Berlin. 
Bauman Zygmunt (1992), Nowoczesność i Zagłada, Masada, Warszawa.

Broswimmer Franz (2002), Ecocide. A Short History of the Mass Extinction of Spieces, Pluto Press, London.

Chakrabarty Dipesh (2014), Klimat historii. Cztery tezy, przeł. Magda Szcześniak, „Teksty Drugie”, nr 5, s. 168-199.

Cobel-Tokarska Marta (2012), Bezludna wyspa, nora, grób. Wojenne kryjówki Żydów w okupowanej Polsce, IPN, Warszawa.

Czapliński Przemysław (2012), Literatura i życie. Perspektywy biopoetyki, w: Teoria, literatura, życie. Praktykowanie teorii w humanistyce wspótczesnej, red. Anna Legeżyńska, Ryszard Nycz, Wydawnictwo IBL PAN, Warszawa.

Dichter Wilhelm (2000), Koń Pana Boga, Znak, Kraków.

Didi-Huberman Georges (2008), Obrazy mimo wszystko, przeł. Mai Kubiak Ho-Chi, Universitas, Kraków.

Domańska Ewa (2013), Humanistyka ekologiczna, „Teksty Drugie”, Warszawa, s. 13-31.

Fiut Aleksander (1998), Natura devorans, natura devorata, w: Moment wieczny. Poezja Czesława Miłosza, Wydawnictwo Literackie, Kraków, s. $67-75$.

Friedlaender Saul (1992), Introduction, w: Probing the Limits of Representation. Nazism and the „Final Solution”, red. Saul Friedlaender, Harvard University Press, Cambridge, s. 5-8. Goślicki Jan (2003), Przedmowa, w: Piotr Rawicz, Krew nieba, przeł. Andrzej Socha, Wydawnictwo Krakowskie, Warszawa, s. 7-17. Grynberg Henryk (1989), Żydowska wojna, Czytelnik, Warszawa. Hilberg Raul (2007), Sprawcy, ofiary, świadkowie. Zagłada Żydów 19391945, przeł. Jerzy Giebułtowski, Centrum Badań nad Zagładą Żydów IFis PAN, Cyklady, Warszawa.

Kwieciński Bartosz (2012), Obrazy i klisze. Między biegunami wizualnej pamięci Zagłady, Universitas, Kraków.

La Capra Dominick (2009), „Traumatropisms”: From Trauma via Witnessing to the Sublime?, w: tegoż, History and Its Limits. Human, Animal, Violence, Cornell University Press, Ithaca-London.

La Capra Dominick (2010), Powrót do pytania o to, co ludzkie i zwierzęce, przeł. Katarzyna Bojarska, w: Teoria wiedzy o przeszłości na tle wspótczesnej humanistyki, red. Ewa Domańska, Wydawnictwo Poznańskie, Poznań.

Latour Bruno (2000), Zirkulierende Referenz. Bodenstichprobe aus dem Urwald Amazonas, w: Die Hoffnung Pandora. Untersuchungen zur Wirklichkeit der Wissenschaft, przeł. Georg Rossler, Suhrkamp Verlag, Frankfurt am Main. 
Latour Bruno (2011), Nigdy nie byliśmy nowocześni. Studium z antropologii symetrycznej, przeł. Maciej Gdula, Oficyna Naukowa, Warszawa.

Levene Mark (2013), „Climate Blues”: or How Awerness of the Human End might Re-instill Ethical Purpose to the Writing of History, „Environmental Humanities”, t. 2, s. 147-167.

Levinas Emmanuel (2000), Bez imienia, w: Imiona wtasne, przeł. Janusz Margański, KR, Warszawa, s. 133-140.

Mazel David (2000), American Literary Environmentalism, The University of Georgia Press, Athens-London.

Morton Timothy (2012), The Oedipal Logic of Ecological Awarness, w: „Environmental Humanities”, nr 1, s. 7-21.

Rabinbach Anson (2003), „The Abyss that opened up before us”: Thinking about Auschwitz and Modernity, w: Catastrophe and Meaning. The Holocaust and the Twentieth Century, red. Eric Santner, Mosze Poistone, The University of Chicago Press, Chicago.

Rawicz Piotr (2003), Krew nieba, przel. Andrzej Socha, Wydawnictwo Krakowskie, Kraków.

Rosenfeld Alvin H. (2003), Wyobraźnia 'in extremis', w: Podwójna śmierć. Rozważania o literaturze Holocaustu, przeł. Barbara Krawcowicz, Cyklady, Warszawa, s. 105-126.

Smith Mick (2013), Ecological Community, the Sense of the World, and Sensless Extinction, „Environmental Humanities”, t. 2, s. 21-41.

Ubertowska Aleksandra (2007), Świadectwo, trauma, głos. Literackie reprezentacje Holokaustu, Universitas, Kraków.

Ubertowska Aleksandra (2013), Natura u kresu (ekocyd). Podmiotowość po katastrofie, „Teksty Drugie”, nr 1-2, s. 33-44.

Wines James (2008), Zielona architektura, przeł. Michał Frankowski, Taschen, Koeln.

Wolfe Cary (2013), Animal studies, dyscyplinarność i post(humanizm), przeł. Karolina Krasucka, „Teksty Drugie”, nr 1-2, s. 125-153.

Ziębinska-Witek Anna (2005), Holocaust. Problemy przedstawiania, Wydawnictwo Umcs, Lublin.

Aleksandra Ubertowska

"Stones are troubled and becoming aggressive". The Holocaust in the Light of Ecocriticism.

The article is an attempt to apply the theoretical and analytical tools derived from ecocriticism and the environmental studies, in the analyses of the literature of the Holocaust. The author proposes a thesis that a full recognition of the role of non-human factors (non-humans), such as 
nature, landscape, climate, plants and animals became only possible after the anthropocentric paradigm in the humanities have been overcome and a new, supra-species kind of "agency"-elaborated from the theory of Brunon Latour-became widespread.

The principal part of the essay contains the analyses of the role of landscape, organic and inorganic nature in the autobiographical prose of Piotr Rawicz, Henryk Grynberg and Wilhelm Dichter. In all of the studied writings nature assumes the function of an ethical subject and additionally the role of anti-historical narration.

Keywords: Holocaust studies; ecocriticism; nature; Bruno Latour; Piotr Rawicz.

Aleksandra Ubertowska - historyk literatury, wykładowca polskiej literatury współczesnej w Instytucie Filologii Polskiej Uniwersytetu Gdańskiego. Obszary jej zainteresowań badawczych to: literatura Holokaustu, etniczność i tożsamość, problematyka podmiotowości w literaturze i filozofii, ekokrytyka. Autorka książek Świadectwo, trauma, głos. Literackie reprezentacje Holokaustu (2007) oraz Holokaust. Auto(tanato)grafie (2014), a także artykułów publikowanych na łamach „Tekstów Drugich”, „Pamiętnika Literackiego”, „Ruchu Literackiego”, tomów pokonferencyjnych polskich i zagranicznych. 
